\title{
Reactions on the mainland to the Taiwanese election
}

Jean-Pierre Cabestan

\section{(2) OpenEdition \\ 1 Journals}

Electronic version

URL: http://journals.openedition.org/chinaperspectives/5897

DOI: 10.4000/chinaperspectives.5897

ISSN: 1996-4617

Publisher

Centre d'étude français sur la Chine contemporaine

\section{Printed version}

Date of publication: 4 June 2012

Number of pages: 85-87

ISSN: 2070-3449

\section{Electronic reference}

Jean-Pierre Cabestan, «Reactions on the mainland to the Taiwanese election », China Perspectives [Online], 2012/2 | 2012, Online since 30 June 2012, connection on 15 September 2020. URL : http:// journals.openedition.org/chinaperspectives/5897 
This section, set by Asia Centre (www.centreasia.eu) is mainly based on the Chinese-language press and aims at explaining the debates ongoing in the PRC, at Hong Kong or in Taiwan on international questions and issues related to Greater China.

\section{China Analysis}

\section{Reactions on the mainland to} the Taiwanese election

\section{Analysis by Jean-Pierre Cabestan based on:}

- Chen Ruoyan, "Different opinions in the Chinese Communist Party over future cross-strait relations," Zhengming, February 2012, pp. 15-16. (1)

- "It's lucky that China has a Taiwan," Kaifang, no. 2, February 2012. (2)

- Zhou Yongkun, "The 'presidential' election in Taiwan and political reform on the mainland," Caijing Blog, 16 January 2012, http://blog.caijing.com.cn/expert_article-151500-32017.shtml (consulted on 20 April 2012). (3)

- Zheng Zhenqing, "Perspectives on the 2012 'presidential election' in Taiwan: Between living standards and the question of identity," author's blog, China Elections, 14 January 2012, http://chinaelections.org/NewsInfo.asp?NewsID=221297 (website temporarily closed at time of editing). (4)

- Guan Ling, "The Taiwan elections must be considered scientifically," 14 January 2012, Jingji guancha wang, China Elections, http://chinaelections.org/NewsInfo.asp?NewsID=221289 (website temporarily closed at time of editing).

- Ding Liting, "Which Taiwan experiences should the mainland study?," author's blog, China Elections, 16 January 2012,

www.chinaelections.org/NewsInfo.asp?NewsID=221364 (website temporarily closed at time of editing).

$\mathrm{T}$ he most unexpected aspect of the recent elections in Taiwan was the interest they generated in China. Taiwan's democratic elections have never before been so closely followed on the other side of the strait. The huge upsurge in interest can be traced back to the rise of social media, particularly micro-blogging. China now has an estimated 250 million bloggers, and as attention focused on the Taiwanese democratic project, many Chinese used the events to raise questions about their own political system. The Hong Kong magazine Zhengming says Kuomintang (KMT) leader Ma Ying-jeou's re-election has given new impetus to the debate within the Chinese Communist Party (CCP) leadership about whether to accelerate the reform process and whether to take more definite steps towards reunification.

\section{Looking for democracy}

In its English version, the establishment newspaper Global Times recognises the depth of mainland Chinese interest in these elections. Nearly 3 million comments about the polls were posted on Sina Weibo, the major Chinese microblog service. ${ }^{(5)}$ Writer Yang Jingjie says the Taiwan polls are a "laboratory of democracy," but he adds comments in Chinese that the election represents a public endorsement of the "1992 consensus," the compromise reached in 1992 by Beijing and Taipei that says there is only one China but that each side is free to interpret in its own way what "one China" means. ${ }^{(6)}$

In its Chinese edition, the Global Times raises the familiar spectre of the break-up of the country to brand as naive bloggers' calls for similar elections on the mainland. (7) In a bilingual editorial, the Global Times says mainland China had a large influence on the outcome of the Taiwan elections: "The
DPP [Democratic People's Party], which denies the 1992 consensus, was defeated twice not only by Ma Ying-jeou, but also, to a large extent, by the power of the Chinese mainland. In one way, the election in Taiwan reflects the rise of China. If the economic development of the Chinese mainland had been in decline for the past eight years, the debates and the results in this year's Taiwan elections would have been quite different." (8)

What fascinated the Chinese bloggers about the elections was the reality of electoral choice. (9) Some users were a little vulgar, like this one from

1. Chen Ruoyan is a journalist for the Hong Kong magazine Zhengming

2. Article by an anonymous Kaifang journalist.

3. Zhou Yongkun is a professor at Suzhou University, Jiangsu.

4. Zheng Zhenqing is an associate professor at the Faculty of Public Administration, Tsinghua University, Beijing.

5. Yang Jingjie, "Millions Follow Taiwan Polls," Global Times, 16 January 2012, www.globaltimes.cn/ NEWS/tabid/99/ID/692291/Millions-follow-Taiwan-poll.aspx (consulted on 20 April 2012).

6. This idea was widely disseminated in the official media: see "Key elections for the people of Taiwan," Renminwang, 14 January 2012, http://tw.people.com.cn/GB/16878101.html (consulted on 20 April 2012); "Taiwanese public opinion: Ma Ying-jeou's victory reflects popular approval of the '1992 consensus' and the peaceful development of cross-strait relations," Xinhuawang, 15 January 2012, www.xinhuanet.com/tw/2012-01/15/c_111439624.htm (no more available at time of editing).

7. See in particular the editorial of Huanqiu shibao - Global Times for 17 January 2012, "Da Zhongguo bushi mianfei wucan." Under this headline, which could be translated literally as "Great China is not a free lunch," the article argues that if China is to be strong and united, the idea of introducing Western-style democracy as in Taiwan must be shelved, http://opinion.huanqiu.com/roll/ 2012-01/2363549.html (consulted on 20 April 2012).

8. Editorial, Global Times, 16 January 2012, http://opinion.huanqiu.com/roll/2012-01/2359674.html (consulted on 20 April 2012).

9. Along with the articles cited at the beginning of this article, some of the blog entries mentioned have been selected and translated into English on the websites China Digital Times and China Media Project. 
Shanghai: "With ballots, Taiwan officials have to bow to the voters; without ballots, the 'Fart People' have to kneel to them." (10) Others used grim humour: "Just now, a Taiwanese friend said to me at the end of our conversation, 'I am going to vote tomorrow morning and by the evening we will know who the President will be.' At the time, I couldn't think how to reply to him. Although we usually have no real barriers in communicating, I was deeply ashamed. I could only say, 'You in Taiwan, you are very backward. If we were having an election tomorrow, we would already know today who would be elected."' (11)

Interestingly, the February 2012 issue of Kaifang carried a very similar joke "The outcome of elections in China is known several years in advance!" But the journal, edited by Jin Zhong and published in Hong Kong, says the joke was made by the economist Han Zhiguo at a meeting in Beijing on $18 \mathrm{Oc}$ tober 2011, which was attended by the relatives of leading officials, including Hu Deping, the son of Hu Yaobang; Luo Diandian, the daughter of Luo Ruiqing; and Xi Qianping, the daughter of Xi Zhongxun (and Xi Jinping's elder sister). ${ }^{(12)}$ Han Zhiguo, whose blog has 3.89 million followers, wrote: "It's lucky that China has a Taiwan (Xingkui Zhongguo you yige Taiwan 幸 亏中国有一个台湾) to show everyone that China, too, has elections!" (13)

Other public figures reacted to the elections, such as famous writer and critic Hao Qun, who writes under the pseudonym Murong Xuecun. He wrote on his microblog: "Whether Ma or Song wins the presidential race in Taiwan, the winner is ultimately Taiwan. This is a victory for the system [that is, Taiwan's political system]." (14) The writer mentions Song Chu-yu, a very minor conservative candidate, and not Tsai Ying-wen, Ma Ying-jeou's real rival: is this ignorance or prudence?

The well-known blogger Yao Bao, who writes under the name Wuyuesanren, also talks about the importance of the electoral process rather than reunification: "The centre of attention in the Taiwan elections has begun to shift from cross-strait relations and Taiwanese independence to the electoral process itself. This reflects a greater awareness of the importance of elections and political rights among those of us who are watching from the sidelines [...] Maybe the real issue is whether both sides of the straits could imagine holding elections like this. If they could, reunification would not be at all controversial." (15)

Many Chinese think the Taiwan elections are re-opening the question of political reform. Some people talked about the history of the KMT, which successfully transitioned from dictatorship to democracy and eventually returned to power through free elections. "The Kuomintang shows us that a political party can reform itself, and that even if it leaves office there is still a chance [for it to return]. But once a party has been overthrown by the people, it's finished." (16)

Ding Liting, another blogger writing on the China Elections website, mentions both the precedent (xianli 先例) and the high stakes of these elections for China: "As reform on the mainland is entering a critical phase (a question of life or death - shengsiyouguan de shike 生死有关的时刻) for the Communist Party, we must remember the following truth: the only basis for power is the genuine and sincere support of the masses! Losing power can also be an opportunity to gain strength by being tested (woxinchangdan 卧薪尝胆), to improve and to reform - in short, to earn a second chance! If the system continues to rely on violence and force, in the current environment of the industrialised market economy, sooner or later, its corruption and illegitimacy will cause it to be overthrown by the popular masses!"

More soberly, and more cautiously, the blogs from the reformist media welcome the maturity (chengshou 承受) of the Taiwanese electorate and politicians. The constitutional expert Zhou Yongkun, a professor at Suzhou University, wrote in his column for Caijing: "The winner did not try to humiliate the loser and the loser accepted defeat gracefully [...These elections] are an encouragement to political reform on the mainland. They show us that in every modern society, whatever the issues, democracy must be taken seriously. I believe that those who promote the idea that 'democracy is not a good thing' cannot find 'a lesser evil to democracy' (bi minzhu geng buhuai 比民主更不坏)."

While praising democracy, this commentary also draws support from a reference to the official intellectual reformist Yu Keping and his careful treatise, Democracy is a good thing (Minzhu shi yige hao dongxi 民主是一个好 东西). ${ }^{(17)}$ But Zhou also makes an argument for liberal democracy that contradicts culturalist arguments against it: "Are there or are there not general principles of modern constitutional democracy? Can constitutional principles that have their origins in Christianity be accepted in countries with non-Christian cultures? [...] does the fact that democracy has its roots in the specific cultural soil of Christianity mean that it 'makes no sense' for people living in non-Christian cultures? The answer is no."

\section{Is there a Republic of China?}

The Taiwan elections have given rise to another line of thinking about the conflict between Beijing and Taipei and the sovereignty of the Republic of China on Taiwan. Ma's re-election seems to justify Hu Jintao's strategy of patience. But Chen Ruoyan writes in Zhengming that the election has reignited debate among some in the Party leadership on the best way to proceed. They feel that the 1992 consensus could lead to a de facto recognition of the existence of the People's Republic of China (PRC) on the mainland and the Republic of China (RoC) on Taiwan. For some of the CCP leadership, this is a depressing situation (jusang 沮丧), because it removes any real prospect of unification.

These concerns suggest the possibility of a shift in mainland thinking on the Republic of China. A comment from Guan Ling on the website of the magazine Jingji Guancha ridicules the idea of denying the existence of the Republic of China: "According to the official history of the People's Republic of China, the Republic of China disappeared in 1949 and was replaced by the PRC. Since then, the island of Taiwan has only had the perverted remnants (yunie 余譬) of the KMT reactionaries. But the Democratic Progressive Party was formed in the early 1980s [in actual fact, it was formed in 1986], thanks to the policy of opening instituted by the then President of the Re-

10. "Taiwan Election on SinaWeibo (Update)," 13 January 2012, http://chinadigitaltimes.net/ 2012/01/taiwans-election-on-sina-weibo (consulted on 20 April 2012). This comment bears a certain resemblance to the saying reported in James C. Scott's Domination and the Arts of Resistance, (Ann Arbor, Yale University, Copyrighted material, 1992), "When the great lord passes, the wise peasant bows deeply and silently farts."

11. Comment from Darkilljou, "Taiwan Election on SinaWeibo (Update)," 13 January 2012, http://chinadigitaltimes.net/2012/01/taiwans-election-on-sina-weibo (consulted on 20 April 2012).

12. Qianping is the given name of Xi An'an, Xi Zhongxun's second daughter.

13. "It's lucky that China has a Taiwan" is also the title of the Kaifang article cited in the sources above.

14. Hao Qun is known for his novel Chengdu, jinye qing jiang wo yiwang, published in English as Leave me alone, a Novel of Chengdu (Allen \& Unwin, 2009). Quoted by Ying Chan, "Elections in Taiwan set the bar for China," China Media Project, 17 January 2012, http://cmp.hku.hk/ 2012/01/17/18035 (consulted on 20 April 2012).

15. Ibid.

16. Ibid.

17. Yu Keping, Democracy is a Good Thing, Washington (DC), Brookings, 2009. Yu Keping is the associate director of the office of documentation and translation of the CCP Central Committee. 
public of China, Chiang Ching-kuo, as well as to his legal and constitutional reforms. Therefore, if you follow the logic of the mainland, the DPP does not exist. All of the DPP's policies, whether on the independence of Taiwan or on rejecting the nuclear option, are the products of a country that has already disappeared (miejue 灭绝)."

Other Internet commentators agree, taking a realistic approach to current developments in Taiwan. In a very detailed analysis of the Taiwan elections, Zheng Zhenqing, an associate professor in the Faculty of Public Administration at Tsinghua University, talks about Taiwanese identity on his blog: "National identity is no longer expressed through a conflict between supporters of unification and supporters of independence; it is instead expressed more subtly in the debate over the 'Taiwanisation of the Republic of China,' which is linked to and interrelates with social policies (minsheng 民生). The recent elections reveal a real rationalisation of policies, and they were on the surface less tense and confrontational than those of 2000, 2004, and 2008. But the complexity of public policy and identity politics has not diminished."

Zheng's last point shows that it is not just the existence but the sovereignty of the RoC that is in question - a serious issue for all Taiwanese people, whatever their partisan affiliations. Although still a delicate subject in the PRC, the question of sovereignty was tackled by Zheng Yongnian, director of the East Asian Institute at the National University of Singapore, in a widely read article in Taiwan's leading Chinese language newspaper, Lianzhe Zaobao (United Morning News). After highlighting the fact that the new situation will force the DPP to moderate its stance on China, Zheng argues that "sovereignty" is distinct from the "right to govern": "China is not claiming the right to govern Taiwan (zhiquan 治权) but only sovereignty (zhuquan 主权) over it. The concept of sovereignty is changing constantly and rapidly, because economic and social interactions across the strait cannot be shut down, and China is also developing a diplomatic culture of respecting differences while seeking harmony (he er bu tong 和而不同) [...] all this should promote the development of a model for mutual relations on both sides of the strait." (18)

Like Chen Ruoyan in Zhengming, Zheng Yongnian thinks some Chinese leaders would like to accelerate the process of reunification. With some justification, some believe that Ma Ying-jeou's opposition to reunification within current political structures (one of his three "nos") shows him to be the main supporter of the "peaceful independence" of Taiwan. However, what Zheng calls "the fever of over-hasty reunification" (jitongzheng 急统 症) is unlikely, he thinks, to catch on with the majority in the Chinese government. The negative effects it would bring about would be quickly felt in terms of national identity and of encouraging a revival of Taiwanese nationalism.

The human dimension of the elections caught the imagination of the Chinese public. As Kaifang and many social media writers said, Tsai Ying-wen, even with her separatist views, charmed more than one Chinese blogger with her style, her frankness, and her struggle for gender equality - a sharp contrast with the male-dominated CCP. The huge interest in these elections on mainland China was attributable to the existence of free choice in Taiwan, the candidates' personality and dignity, and the impossibility of not comparing the Taiwanese example to the situation in China. Will this encourage a return to debate on reform in China - or will it instead push the CCP leadership to demand more from MaYing-jeou?

\section{Translated by Jonathan Hall}

18. Zheng Yongnian, "Taiwanese democracy and the future of cross-strait relations," Lianhe Zaobao, 31 January 2012, www.zaobao.com/special/forum/pages8_zp12013a.shtml (no more available at time of editing). 